\title{
The relationship between microstructure and fracture toughness of zirconia toughened alumina (ZTA) added with $\mathrm{MgO}$ and $\mathrm{CeO}_{2}$
}

\author{
Nik Akmar Rejab a , Ahmad Zahirani Ahmad Azhar a, Mani Maran Ratnam ${ }^{\text {b }}$, Zainal Arifin Ahmad ${ }^{\text {a,* }}$ \\ a Structural Materials Niche Area, School of Materials and Mineral Resources, Engineering Campus, Universiti Sains Malaysia, 14300 Nibong Tebal, Penang, Malaysia \\ b School of Mechanical Engineering, Engineering Campus, Universiti Sains Malaysia, 14300 Nibong Tebal, Penang, Malaysia
}

\section{A R T I C L E I N F O}

Article history:

Received 22 February 2013

Accepted 17 July 2013

\section{Keywords:}

Microstructure

Vickers hardness

Fracture toughness

Palmqvist crack

\begin{abstract}
A B S T R A C T
The aim of this research is to investigate the mode of crack propagation in zirconia toughened alumina (ZTA) added with $\mathrm{MgO}$ and $\mathrm{CeO}_{2}$, respectively. The mode of crack refers to the toughening mechanism of the materials. Different ZTA compositions containing $\mathrm{MgO}$ and $\mathrm{CeO}_{2}$ as sintering additives were prepared using pressureless sintering at $1600{ }^{\circ} \mathrm{C}$. Each sample was subjected to Vickers indentation with $294 \mathrm{~N}$ load and the cracks that propagated were observed with SEM. The ZTA with an addition of $0.7 \mathrm{wt} . \% \mathrm{MgO}$ showed a crack deflection with a fracture toughness value of $6.19 \pm 0.26 \mathrm{MPa} \cdot \sqrt{\mathrm{m}}$. On the other hand, the $\mathrm{ZTA}$ with $\mathrm{CeO}_{2}$ addition of 0.5 to $7 \mathrm{wt} . \%$ showed both crack bridging and deflection, and produced $5.78 \pm 0.16 \mathrm{MPa} \cdot \sqrt{\mathrm{m}}$ to $6.59 \pm 0.23 \mathrm{MPa} \cdot \sqrt{\mathrm{m}}$ fracture toughness values, respectively. The fracture toughness of the $\mathrm{ZTA}-\mathrm{MgO}-\mathrm{CeO}_{2}$ compositions is higher due to crack bridging and crack deflection. The toughening mechanisms of crack deflection and bridging hinder crack propagation since more energy is required to make the crack propagate. However, the formation of $\mathrm{CeAl}_{11} \mathrm{O}_{18}$ phase was observed; this consequently decreases the hardness and fracture toughness of the ZTA$\mathrm{MgO}-\mathrm{CeO}_{2}$ compositions.
\end{abstract}

(c) 2013 Elsevier Ltd. All rights reserved.

\section{Introduction}

$\mathrm{Al}_{2} \mathrm{O}_{3}$ can be considered as an all-rounded material for engineering ceramics. The properties of this ceramic are particularly attractive for structural applications such as in motor, aerospace, and biomedical fields, especially in severe environmental conditions [1]. Brittleness and poor damage tolerance have limited the scope of use as advanced engineering materials for almost all composition materials [2]. The fracture toughness of composition materials is generally low because the dislocation motion in the material is extremely limited due to the nature of the chemical bonds which are ionic and/or covalent. The problem of low fracture toughness in the ceramics can be overcome by designing and preparing the composite materials reinforced with fibers, whiskers, and particulates of the same phase as that of the matrix or of a different but suitable phase. The use of $\mathrm{ZrO}_{2}$-based ceramics is one of the possible alternatives to circumvent the limitation of low fracture toughness [3,4].

In spite of the variety of useful physical properties of sintered oxide ceramics that are based on chemically and thermally stable modification of $\alpha-\mathrm{Al}_{2} \mathrm{O}_{3}$, their application as cutting tool inserts working under mechanical loads and thermal shock conditions is limited due to their brittleness and low strength. To overcome the brittleness, reinforcement such as YSZ is introduced into $\mathrm{Al}_{2} \mathrm{O}_{3}$, producing zirconia

\footnotetext{
* Corresponding author. Tel.: + 604 5996128; fax: + 6045941011. E-mail address: zainal@eng.usm.my (Z.A. Ahmad).
}

toughened alumina (ZTA). YSZ increases the toughness by transforming the phase from $\mathrm{ZrO}_{2(\mathrm{t})}$ to $\mathrm{ZrO}_{2(\mathrm{~m})}$ [5-7].

Zirconia toughened $\mathrm{Al}_{2} \mathrm{O}_{3}$ (ZTA) has been reported to be one of the most successful commercial ceramic-based cutting inserts which fully utilize the advantages of zirconia [2]. Recently, materials with certain intermetallic matrices were reported to may also benefit from the addition of zirconia particles. Dogan and Hawk applied 20 mass\% of zirconia into $\mathrm{MoSi}_{2}$ system which resulted in a $25-100 \%$ increase in fracture toughness of the material, depending upon which toughening mechanisms are activated.

Because strengthening increases linearly with the amount of tetragonal phase, zirconia with $100 \%$ of tetragonal phase gives the highest strength. In addition, zirconia with $100 \%$ of tetragonal phase is known as tetragonal zirconia polycrystals (TZP). The amount of oxide added must be limited so that the phase is still tetragonal during sintering. On the other hand, the amount must not be too small because the transformation of the tetragonal grains to the monoclinic state cannot be suppressed [8].

Previous works [9-14] have investigated the effects of various additives on the microstructural, mechanical properties, and tool wear of ZTA composites. Furthermore, their analysis has also proven that ZTA composite is an excellent candidate for cutting insert applications. However, their investigation on the toughness and crack behavior properties were not thorough as they only measured the fracture toughness of the composite, but did not observe and/or investigate the crack propagation behavior of their ceramic compositions. 
Therefore, the influence of sintering additives, such as $\mathrm{MgO}$ and $\mathrm{CeO}_{2}$ with different volume fractions on the microstructural characteristics, fracture toughness, and crack behavior of ZTA compositions was investigated. The fracture toughness and hardness of each sample were determined at room temperature. In addition, bulk density, Vickers hardness, and phase identification of the sintered samples which are also dependent on sintering additives were determined.

\section{Materials and methodology}

Starting powders of highly pure, thermally reactive type $\mathrm{Al}_{2} \mathrm{O}_{3}$ (Alcoa, A16SG, 99.0\%), yttrium stabilized zirconia (Goodfellow, 94.6\%), $20 \mathrm{~nm} \mathrm{MgO}$ (Strem Chemicals, Inc., 99.9\%), and $\mathrm{CeO}_{2}$ (Sigma-Aldrich Corporation, 99.0\%) were used. The particle size analysis of starting materials was carried out with Sympatec Nanophox (NX0064). In this work, 80 wt.\% of $\mathrm{Al}_{2} \mathrm{O}_{3}$ and 20 wt.\% yttrium stabilized zirconia were taken as the baseline composition. The amount of $\mathrm{MgO}$ was fixed at 0.7 wt.\% due to its excellent hardness values [9]. The ceria were added in different wt.\% (0.5 to 7 wt.\%) into the initial compositions. Table 1 shows the addition in weight percentage (wt.\%) for each powder composition used. The mixtures were prepared by the wet milling method. Subsequently, the mixtures were dried to $100^{\circ} \mathrm{C}$ and crushed to form powders. Cylindrical shapes with dimensions of $13.0 \mathrm{~mm}$ in diameter and $4.0 \mathrm{~mm}$ in height were formed by pressing the crushed powder at $300 \mathrm{MPa}$. Afterwards, these cylindrical samples were sintered in atmosphere at $1600{ }^{\circ} \mathrm{C}$ for $4 \mathrm{~h}$ to yield dense ceramics.

The density and porosity values were obtained according to the ASTM C 830-00 test procedure. The analysis of crystal structure was carried out by X-ray diffraction (XRD) using the Bruker D8 Advance with CuKa radiation $(40 \mathrm{kV}, 30 \mathrm{~mA})$ diffracted beam monochromator, using a step scan mode with a step size of $0.1^{\circ}$ in the range of $20^{\circ}-80^{\circ}$ of $2 \theta^{\circ}$. Scanning electron microscopy (SEM) was employed to study the microstructure of the polished samples. The IMT iSolution DT software was used to discriminate and measure the percentage of each phase from the SEM microstructure. The fracture toughness, which is a critical mechanical property parameter in this work, was determined by the indentation technique. The samples were carefully diamondpolished to produce an optical finish. In the indentation test (Shimadzu Vickers hardness tester HSV-20, Japan), a 294 N load was applied by pressing the indenter onto the sample surface. Both the diagonal length of the indentation and crack length were measured. 10 indent points were made for each sample and the average was taken. $\mathrm{K}_{1 \mathrm{C}}(\mathrm{HV} 30)$ was calculated using Eq. (1) [15]:

$3 \mathrm{~K}_{\mathrm{Ic}}=0.035\left(\mathrm{Ha}^{1 / 2}\right)(3 \mathrm{E} / \mathrm{H})^{0.4}(\mathrm{l} / \mathrm{a})^{-0.5}$

where $\mathrm{K}_{1 \mathrm{C}}$ is the fracture toughness, $\mathrm{H}$ is Vickers hardness, a is the half length of Vickers diagonal ( $\mu \mathrm{m}), \mathrm{E}$ is the Young modulus of the samples, and $l$ is the length of the radial crack size $(\mu \mathrm{m})$. Young modulus for all the samples was determined using rules of mixtures and calculated with respect to the composition of each sample.

Table 1

Addition of $\mathrm{CeO}_{2}$ in weight percentage (wt.\%) for each composition.

\begin{tabular}{lcll}
\hline Sample & $\mathrm{ZTA}$ & $\mathrm{MgO}$ (wt.\%) & $\mathrm{CeO}_{2}$ (wt.\%) \\
\hline ZTA & 100 & 0.0 & 0.0 \\
$\mathrm{ZTA}-\mathrm{MgO}$ & 99.3 & 0.7 & 0.0 \\
$\mathrm{ZTA}-\mathrm{MgO}-0.5 \mathrm{CeO}_{2}$ & 98.8 & 0.7 & 0.5 \\
$\mathrm{ZTA}-\mathrm{MgO}-0.7 \mathrm{CeO}_{2}$ & 98.6 & 0.7 & 0.7 \\
$\mathrm{ZTA}-\mathrm{MgO}-1.0 \mathrm{CeO}_{2}$ & 98.3 & 0.7 & 1.0 \\
$\mathrm{ZTA}-\mathrm{MgO}-5.0 \mathrm{CeO}_{2}$ & 94.3 & 0.7 & 5.0 \\
$\mathrm{ZTA}-\mathrm{MgO}-7.0 \mathrm{CeO}_{2}$ & 92.3 & 0.7 & 7.0 \\
\hline
\end{tabular}

* Composition of all ZTA was fixed to 80 wt.\% $\mathrm{Al}_{2} \mathrm{O}_{3}$ and 20 wt.\% YSZ.

\section{Results and discussion}

Fig. 1 shows the average particle size, particle size distribution, and morphology for all of the raw powders used. The average particle sizes for $\mathrm{Al}_{2} \mathrm{O}_{3}$ and $\mathrm{YSZ}$ were $1.05 \mu \mathrm{m}$ and $0.71 \mu \mathrm{m}$, while the $\mathrm{MgO}$ nano particle and $\mathrm{CeO}_{2}$ powder were $18.35 \mathrm{~nm}$ and $138.69 \mathrm{~nm}$, respectively. Table 2 summarizes the overall results for grain size, Vickers hardness, fracture toughness, theoretical density, bulk density, and porosity. The comparison of crack propagation between pure $\mathrm{Al}_{2} \mathrm{O}_{3}$ and ZTA is shown in Fig. 2. The scanning electron microscope (SEM) micrographs of the indentation show cracks emanating from the corners of the Vickers indentation. The crack mode for both samples resulted in some crack deflections, as indicated by the white arrows at the $\mathrm{Al}_{2} \mathrm{O}_{3}$ and YSZ grains. However, the propagated crack experienced less deflection in pure $\mathrm{Al}_{2} \mathrm{O}_{3}$ compared to ZTA; the crack directly propagated through these grains, showing transgranular tendency. ZTA samples show more crack deflection due to the presence of $t \rightarrow m$ phase transformation during the crack propagation. A similar observation was reported by previous authors $[16,17]$. The behavior of crack propagation for $\mathrm{Al}_{2} \mathrm{O}_{3}$ would suggest that $\mathrm{Al}_{2} \mathrm{O}_{3}$ fracture toughness is lower compared to ZTA. The values of fracture toughness for $\mathrm{Al}_{2} \mathrm{O}_{3}$ and ZTA are $2.85 \pm 0.40 \mathrm{MPa} \cdot \sqrt{\mathrm{m}}$ and $4.42 \pm 0.35 \mathrm{MPa} \cdot \sqrt{\mathrm{m}}$, respectively. Although sintered $\mathrm{Al}_{2} \mathrm{O}_{3}$ shows a larger grain size $(4.30 \pm 3.00 \mu \mathrm{m})$ compared to ZTA, their fracture toughness was reported to be lower [11].

Fig. 3 shows the indentation profile for the sample ZTA-MgO with $0 \mathrm{wt} . \% \mathrm{CeO}_{2}$. An enlarged view of one crack path is shown in an inset in Fig. 3. The crack path, as can be seen in the inset, indicates the crack propagation with associated crack deflection behavior on the surface. Fig. 4 (a)-(b) shows the surface morphology of cracks for samples ZTA-MgO and ZTA-MgO-0.7 wt.\% $\mathrm{CeO}_{2}$, respectively. The crack deflection can be observed under indentation load of $294 \mathrm{~N}$. The fracture toughness value for $\mathrm{ZTA}-\mathrm{MgO}-0 \mathrm{wt} . \% \mathrm{CeO}_{2}$ (baseline sample) and ZTA-MgO-1.0 wt.\% $\mathrm{CeO}_{2}$ were $5.75 \pm 0.33 \mathrm{MPa} \cdot \sqrt{\mathrm{m}}$ and $6.59 \pm$ $0.23 \mathrm{MPa} \cdot \sqrt{ } \mathrm{m}$, respectively. ZTA-MgO-1.0 wt.\% $\mathrm{CeO}_{2}$ has higher fracture toughness due to a higher number of crack deflections found on the crack propagation compared to a sample of ZTA-MgO-0 wt.\% $\mathrm{CeO}_{2}$, as shown in Fig. 4 . With the presence of $\mathrm{CeO}_{2}$, ZTA- $\mathrm{CeO}_{2}$ samples show more crack deflection due to $\mathrm{Al}_{2} \mathrm{O}_{3}$ strengthening by $\mathrm{CeO}_{2}$ [14].

Besides the modes of crack propagation in ZTA, the presence of YSZ in the $\mathrm{Al}_{2} \mathrm{O}_{3}$ clearly contributed to the increase of fracture toughness. XRD spectra of the ZTA-MgO- $\mathrm{CeO}_{2}$ compositions sintered at $1600{ }^{\circ} \mathrm{C}$ for $4 \mathrm{~h}$ are shown in Fig. 5. From the XRD patterns, it is observed that the major diffraction peaks can be indexed as yittria doped zirconia $\left(\mathrm{Zr}_{0.935} \mathrm{Y}_{0.065}\right) \mathrm{O}_{1.968}$ (designated as ${ }^{\mathrm{O}}$, ICDD files No. 01-078-1808), and $\alpha-\mathrm{Al}_{2} \mathrm{O}_{3}$ (designated as $\square$, ICDD files No. 00-010-0173). Three minor phases were also identified, i.e., $\mathrm{m}-\mathrm{ZrO}_{2}$ (designated as *, ICDD files No. 01-078-1807), $\mathrm{MgAl}_{2} \mathrm{O}_{4}$ (designated as $\diamond$, ICDD files No. 01-0731959), and $\mathrm{CeAl}_{11} \mathrm{O}_{18}$ (designated as $\Delta$, ICDD files No. 00-048-0055). Various literatures $[1,8,18,19]$ suggest that the transformation toughening inside ZTA is an efficient mechanism that improves the toughness of ceramic composites containing YSZ. Furthermore, addition of $\mathrm{CeO}_{2}$ also acts as a stabilizing agent. XRD results in Fig. 5 show that the peak for the monoclinic phase decreases with increased addition of $\mathrm{CeO}_{2}$. The reduction of the monoclinic phase resulted in the increase of the tetragonal phase, thus promoting more transformation toughening $t \rightarrow m$ in ZTA ceramic composites. The addition of $\mathrm{CeO}_{2}$ also decreases the monoclinic phase, as shown at $28^{\circ}$ and $32^{\circ}$ Bragg angles. Previous work done by Huang et al., who studied the reduction of $\mathrm{CeO}_{2}$ in $\mathrm{ZrO}_{2}$ ceramics, also shows a reduction of the monoclinic phase with the addition of $\mathrm{CeO}_{2}$ [20]. The reduction of the monoclinic phase in $\mathrm{ZTA}-\mathrm{MgO}-\mathrm{CeO}_{2}$ system increases the overall toughness of the ceramic composite. This is due to the presence of more tetragonal $\mathrm{ZrO}_{2}$, which promotes the transformation toughening mechanism. A similar observation was also reported by Azhar et al. and Rejab et al. on the $\mathrm{ZTA}-\mathrm{Cr}_{2} \mathrm{O}_{3}$ system where the presence of $\mathrm{Cr}_{2} \mathrm{O}_{3}$ can be used to lower the presence of the monoclinic phase. The presence of monoclinic zirconia phase was an unavoidable 

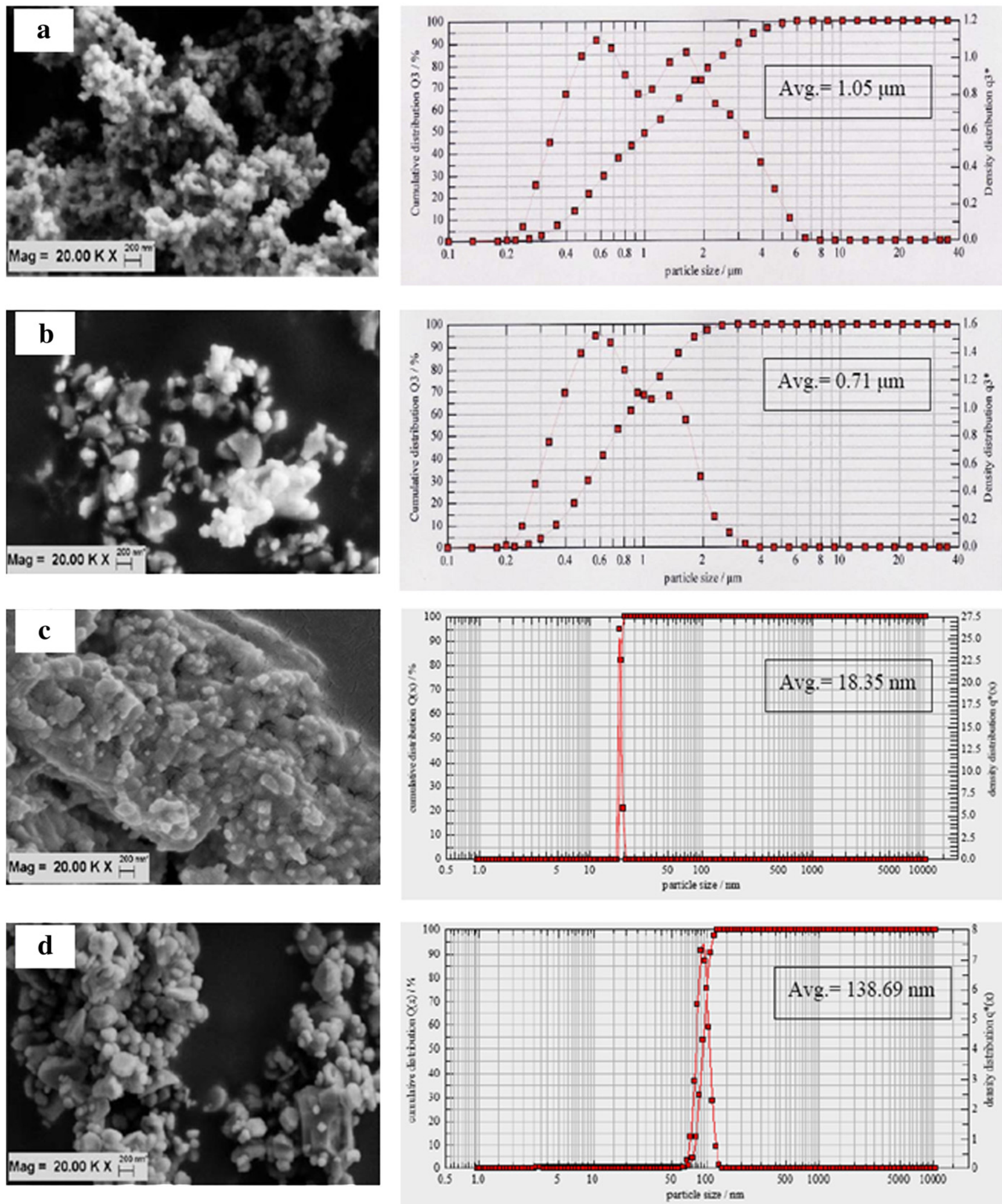

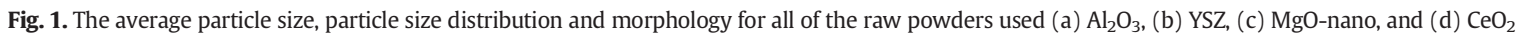

phenomenon and the small amount of monoclinic $\mathrm{ZrO}_{2}$ would not affect the mixture as a whole. Sergo et al. reported that at least $15 \%$ of monoclinic phase will always be present, even in zirconia toughened alumina (ZTA) commercial cutting tools [21]. The presence of $\mathrm{MgAl}_{2} \mathrm{O}_{4}$ phase was first detected for ZTA-MgO without $\mathrm{CeO}_{2}$ addition (Fig. 5b). The $\mathrm{MgAl}_{2} \mathrm{O}_{4}$ peaks were more apparent at the Bragg angle of $37.02^{\circ}$, as shown in Fig. 5. An image analyzer proved that the percentage area of $\mathrm{MgAl}_{2} \mathrm{O}_{4}$ phase at 0.5 to $1.0 \mathrm{wt} . \% \mathrm{CeO}_{2}$ addition was diminished from 
Table 2

Physical and mechanical properties of ZTA-MgO with various amounts of $\mathrm{CeO}_{2}$ addition.

\begin{tabular}{|c|c|c|c|c|c|c|c|}
\hline \multirow[t]{2}{*}{ Composition } & \multicolumn{2}{|c|}{ Grain size $(\mu \mathrm{m})$} & \multirow{2}{*}{$\begin{array}{l}\text { Hardness } \\
(\mathrm{GPa})\end{array}$} & \multirow{2}{*}{$\begin{array}{l}\text { Fracture toughness } \\
(\mathrm{MPa} \cdot \sqrt{\mathrm{m}})\end{array}$} & \multirow{2}{*}{$\begin{array}{l}\text { Theoretical density } \\
\left(\mathrm{g} / \mathrm{m}^{3}\right)\end{array}$} & \multirow{2}{*}{$\begin{array}{l}\text { Bulk density } \\
\left(\mathrm{g} / \mathrm{m}^{3}\right)\end{array}$} & \multirow{2}{*}{$\begin{array}{l}\text { Porosity } \\
(\%)\end{array}$} \\
\hline & YSZ & $\mathrm{Al}_{2} \mathrm{O}_{3}$ & & & & & \\
\hline ZTA & $1.21 \pm 0.30$ & $2.67 \pm 0.45$ & $15.30 \pm 0.28$ & $5.75 \pm 0.33$ & 4.40 & 4.13 & 1.66 \\
\hline ZTA-MgO & $1.48 \pm 0.28$ & $2.14 \pm 0.82$ & $14.31 \pm 0.15$ & $5.77 \pm 0.15$ & 4.43 & 4.18 & 3.05 \\
\hline ZTA-MgO-0.5CeO & $1.57 \pm 0.34$ & $2.88 \pm 0.54$ & $14.62 \pm 0.22$ & $5.78 \pm 0.16$ & 4.47 & 4.21 & 2.32 \\
\hline ZTA-MgO-0.7CeO & $1.65 \pm 0.60$ & $2.94 \pm 0.69$ & $14.83 \pm 0.27$ & $6.19 \pm 0.26$ & 4.48 & 4.25 & 0.45 \\
\hline ZTA-MgO-1.0CeO & $1.67 \pm 0.37$ & $2.95 \pm 0.63$ & $14.99 \pm 0.31$ & $6.59 \pm 0.23$ & 4.50 & 4.28 & 0.48 \\
\hline ZTA-MgO-5.0CeO & $1.89 \pm 0.41$ & $2.98 \pm 0.56$ & $14.52 \pm 0.23$ & $5.72 \pm 0.25$ & 4.79 & 4.25 & 0.42 \\
\hline ZTA-MgO-7.0CeO & $1.91 \pm 0.46$ & $2.86 \pm 0.49$ & $14.15 \pm 0.19$ & $5.58 \pm 0.20$ & 4.94 & 4.27 & 1.62 \\
\hline
\end{tabular}

3.31 to $1.73 \%$. Further addition of 5.0 to $7.0 \mathrm{wt} . \% \mathrm{CeO}_{2}$ caused the $\mathrm{MgAl}_{2} \mathrm{O}_{4}$ peaks to disappear and the new phase formation of $\mathrm{CeAl}_{11} \mathrm{O}_{18}$ to appear.

The addition of $5.0 \mathrm{wt} . \%$ and $7.0 \mathrm{wt} . \%$ of $\mathrm{CeO}_{2}$ resulted in the formation of $\mathrm{CeAl}_{11} \mathrm{O}_{18}$. This is shown in the Bragg angle of $29^{\circ}-37^{\circ}$ in Fig. 5. The presence of $\mathrm{CeAl}_{11} \mathrm{O}_{18}$ could be due to solubility limits being exceeded because of excessive $\mathrm{CeO}_{2}$ addition in the $\mathrm{ZTA}-\mathrm{MgO}$ compositions. According to the literature, the excess $\mathrm{Ce}^{4+}$ in the ZTA-MgO compositions form minority phases or segregate from the interior grain and
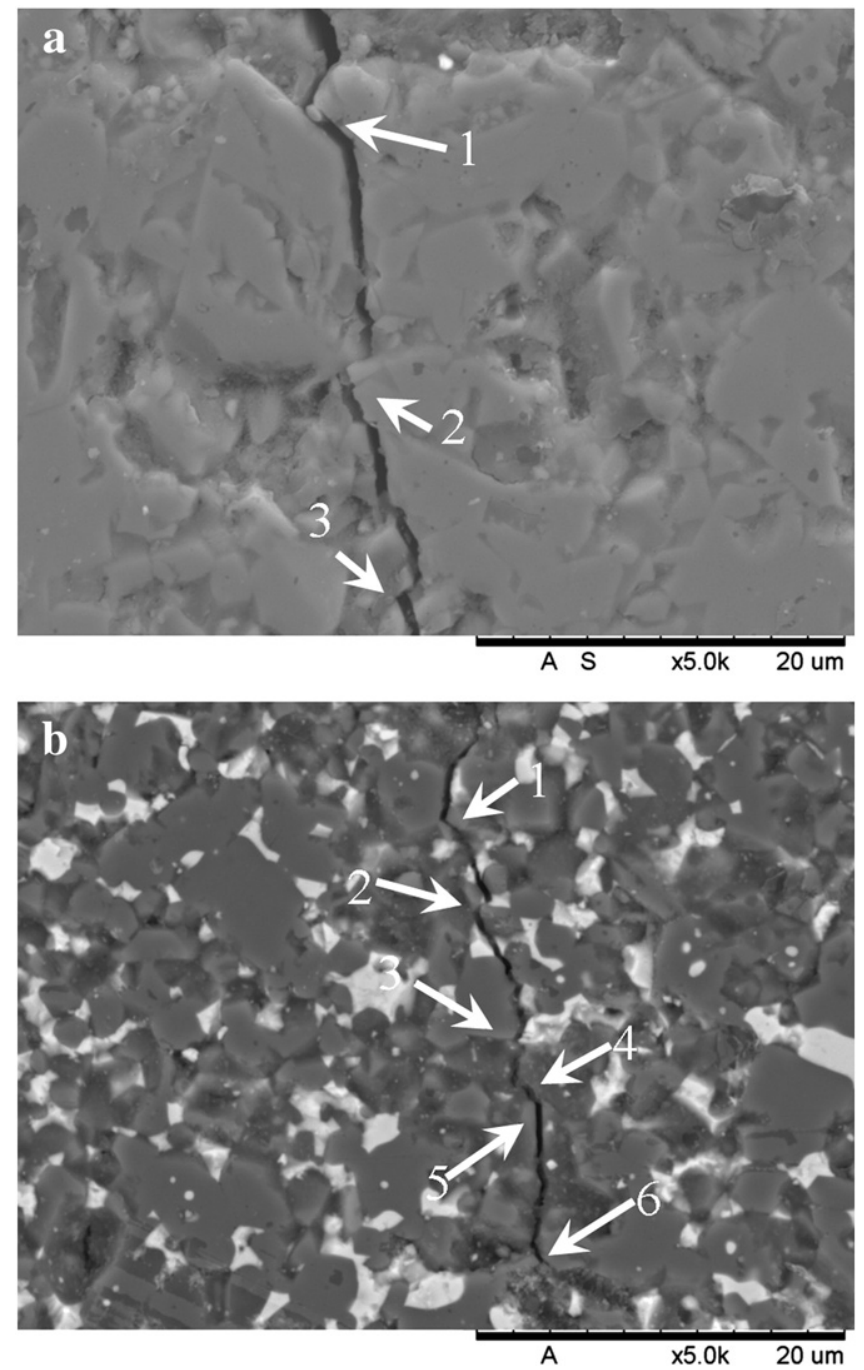

Fig. 2. Crack deflection comparison between (a) pure $\mathrm{Al}_{2} \mathrm{O}_{3}$, and (b) ZTA composite sintered at $1600{ }^{\circ} \mathrm{C}$ for $4 \mathrm{~h}$. Crack propagation is downward. move into the perovskite lattice, as observed by other authors $[20,22]$. The presence of the $\mathrm{CeAl}_{11} \mathrm{O}_{18}$ phase could affect the toughening mechanism. Akin et al. reported that the $\mathrm{CeAl}_{11} \mathrm{O}_{18}$ phase formation is associated with a reduction of $\mathrm{CeO}_{2}$ to $\mathrm{Ce}_{2} \mathrm{O}_{3}$ and a reaction with $\mathrm{Al}_{2} \mathrm{O}_{3}$ at higher temperatures of around $1200-1400{ }^{\circ} \mathrm{C}$ [22]. The formation of the $\mathrm{CeAl}_{11} \mathrm{O}_{18}$ phase could be related to the reduction of $\mathrm{CeO}_{2}$ to $\mathrm{Ce}_{2} \mathrm{O}_{3}$ and a reaction with $\mathrm{Al}_{2} \mathrm{O}_{3}$ at higher temperatures of around $1200-1400{ }^{\circ} \mathrm{C}$, according to the following equation [22];

$$
\mathrm{Ce}_{2} \mathrm{O}_{3}+11 \mathrm{Al}_{2} \mathrm{O}_{3} \rightarrow \mathrm{Ce}_{2} \mathrm{O}_{3} \cdot 11 \mathrm{Al}_{2} \mathrm{O}_{3} \text {. }
$$

Fig. 6 shows the area percentages of each phase in the ZTA-MgO$\mathrm{CeO}_{2}$ composites. The $\mathrm{CeAl}_{11} \mathrm{O}_{18}$ phase started to appear at $1 \mathrm{wt} \%$ and kept increasing until 7 wt.\% $\mathrm{CeO}_{2}$ addition, i.e., from $17.28 \%$ to $47.66 \%$. The increase of $\mathrm{CeAl}_{11} \mathrm{O}_{18}$ phase reduced the toughness of the sample. At the same time, the percentage of yttria doped zirconia $\left\{\left(\mathrm{Zr}_{0.935} \mathrm{Y}_{0.065}\right)\right.$ $\mathrm{O}_{1.968}$ \} phase (tetragonal structure) decreased from $18.35 \%$ to $12.36 \%$. Therefore, due to the loss of this tetragonal phase in YSZ, the toughness also decreases. Table 3 shows the results of phase percentage area of each $\mathrm{ZTA}-\mathrm{MgO}-\mathrm{CeO}_{2}$ composite. It is proven that the addition of $\mathrm{CeO}_{2}$ does reduce the tetragonal phase; hence, the decrease of fracture toughness is due to the loss of tetragonal phase. The percentage of yittria doped zirconia $\left(\mathrm{Zr}_{0.935} \mathrm{Y}_{0.065}\right) \mathrm{O}_{1.968}$ phase (tetragonal structure) dropped from $18.35 \%$ to $12.36 \%$. The highest reduction recorded for $\alpha-\mathrm{Al}_{2} \mathrm{O}_{3}$ (corundum) was from $81.71 \%$ to $38.54 \%$. High phase percentage reduction for $\alpha-\mathrm{Al}_{2} \mathrm{O}_{3}$ refers to the presence of residual stress which is shown through some shifting in $\alpha-\mathrm{Al}_{2} \mathrm{O}_{3}$ and YSZ peaks that were observed due to $\mathrm{CeO}_{2}$ addition. The XRD peak shift occurred due to the presence of residual stress as the ionic radii for $\mathrm{Ce}^{4+}(0.96)$ and $\mathrm{Al}^{3+}(0.51)$ and differs significantly in the case of a substitutional solid solution. The stress relieved

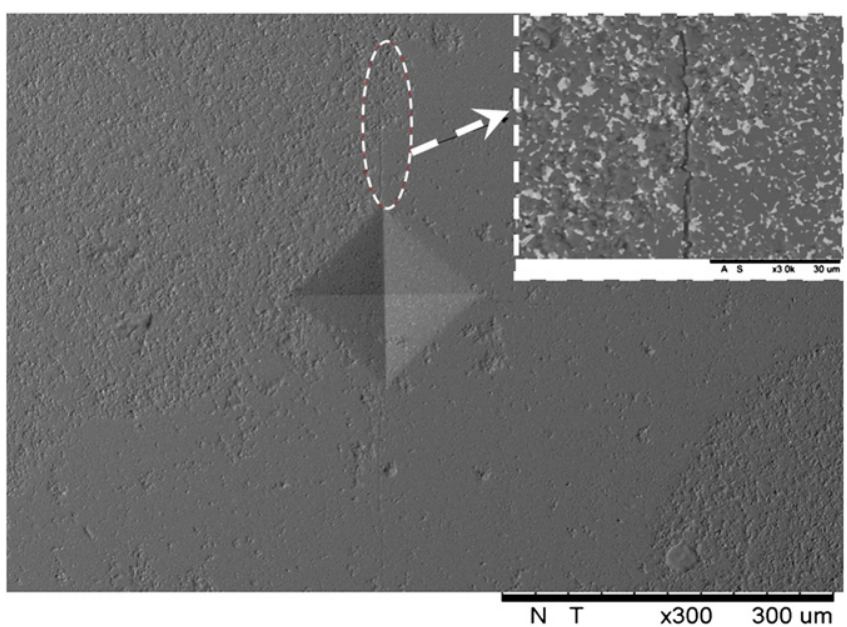

Fig. 3. The SEM micrograph of indent under a load of $294 \mathrm{~N}$ for sample ZTA-MgO without addition of $\mathrm{CeO}_{2}$. 

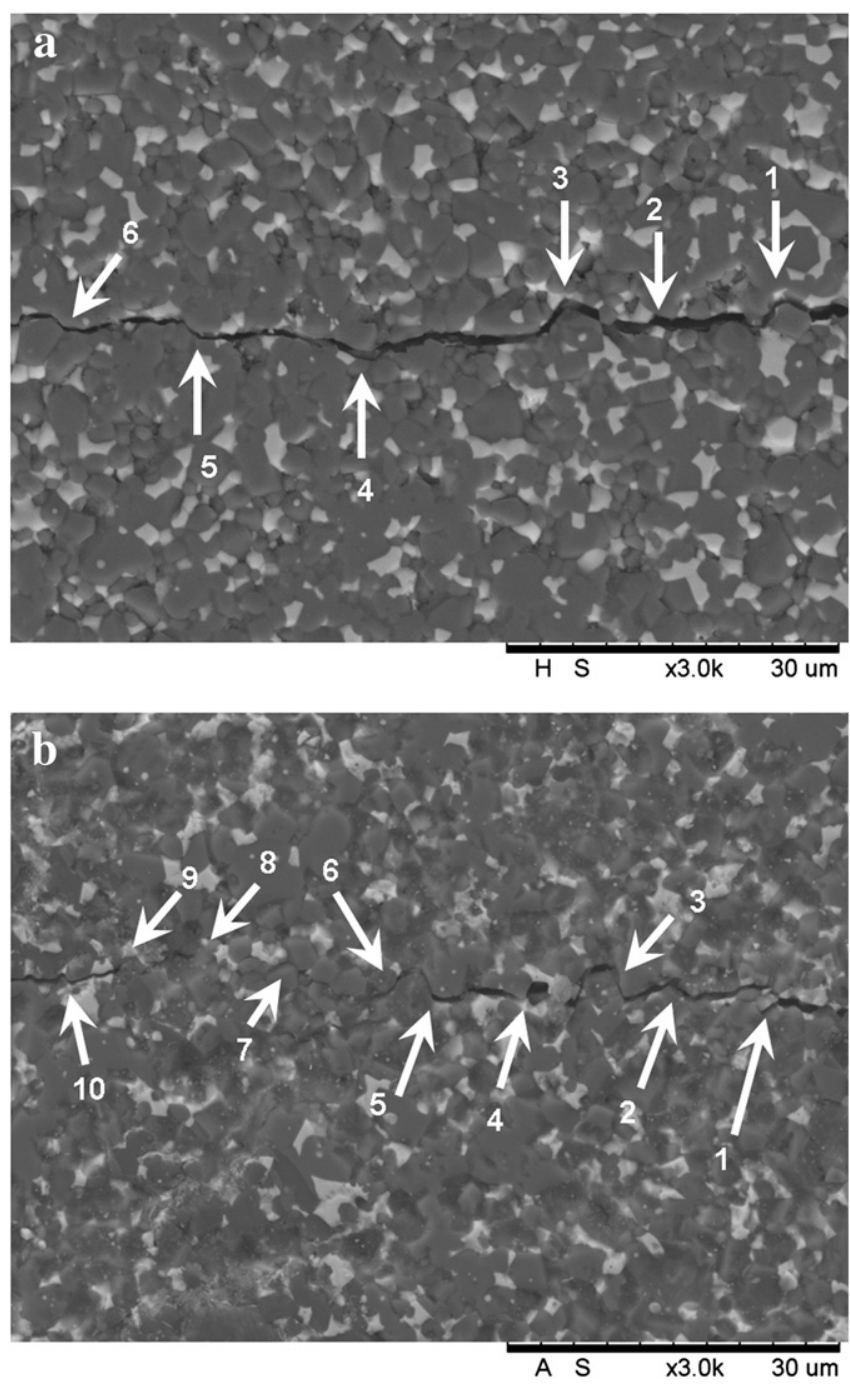

Fig. 4. Crack path in the (a) $\mathrm{ZTA}-\mathrm{MgO}$ without $\mathrm{CeO}_{2}$ and (b) $\mathrm{ZTA}-\mathrm{MgO}-1.0$ wt.\% $\mathrm{CeO}_{2}$, induced by Vickers indentation. Arrows indicate that major toughening mechanisms are crack deflection.

from the sintering process contributed to the peak shifting in the XRD pattern of $\mathrm{ZTA}-\mathrm{MgO}-\mathrm{CeO}_{2}$ composites.

The crack propagation behavior of ZTA- $\mathrm{MgO}-\mathrm{CeO}_{2}$ composites are known to affect the fracture toughness of the samples [19]. The results for fracture toughness and Vickers hardness are shown in Fig. 7. The results of fracture toughness increased from $5.75 \pm 0.33 \mathrm{MPa} \cdot \sqrt{ } \mathrm{m}$ to $6.59 \pm 0.23 \mathrm{MPa} \cdot \sqrt{\mathrm{m}}$ with the addition of $1.0 \mathrm{wt} . \%$ of $\mathrm{CeO}_{2}$. According to the XRD pattern (Fig. 5), addition of $\mathrm{CeO}_{2}$ reduces the monoclinic phase, as shown at $28^{\circ}$ and $32^{\circ}$ Bragg angles. Due to the disappearance of the monoclinic phase, the fracture toughness of the ZTA sample increased from $5.75 \mathrm{MPa} \cdot \sqrt{\mathrm{m}}$ to $6.59 \mathrm{MPa} \cdot \sqrt{ } \mathrm{m}$ with the addition of $1.0 \mathrm{wt} . \%$ of $\mathrm{CeO}_{2}$. Furthermore, the increment in the intrinsic toughness of alumina matrix and toughening mechanism introduced by zirconia particles as transformation toughening $(t \rightarrow m)$ also contributed to the increase in fracture toughness. However, secondary phase $\left(\mathrm{CeAl}_{11} \mathrm{O}_{18}\right)$ was detected at 5.0 wt.\% and $7.0 \mathrm{wt} . \%$ of $\mathrm{CeO}_{2}$ addition which decreased the fracture toughness to $5.72 \pm 0.25 \mathrm{MPa} \cdot \sqrt{\mathrm{m}}\left(5.0 \mathrm{wt} . \%\right.$ of $\left.\mathrm{CeO}_{2}\right)$ and $5.58 \pm 0.20 \mathrm{MPa} \cdot \sqrt{\mathrm{m}}\left(7.0 \mathrm{wt} . \%\right.$ of $\left.\mathrm{CeO}_{2}\right)$, respectively. The sample with 1.0 wt.\% $\mathrm{CeO}_{2}$ addition showed the highest value which is $6.59 \pm 0.23 \mathrm{MPa} \cdot \sqrt{\mathrm{m}}$. The increase of the fracture toughness of the $\mathrm{ZTA}-\mathrm{MgO}-\mathrm{CeO}_{2}$ compositions, as compared to the ZTA compositions, is obvious from the presence of crack deflection and bridging. Both cracks

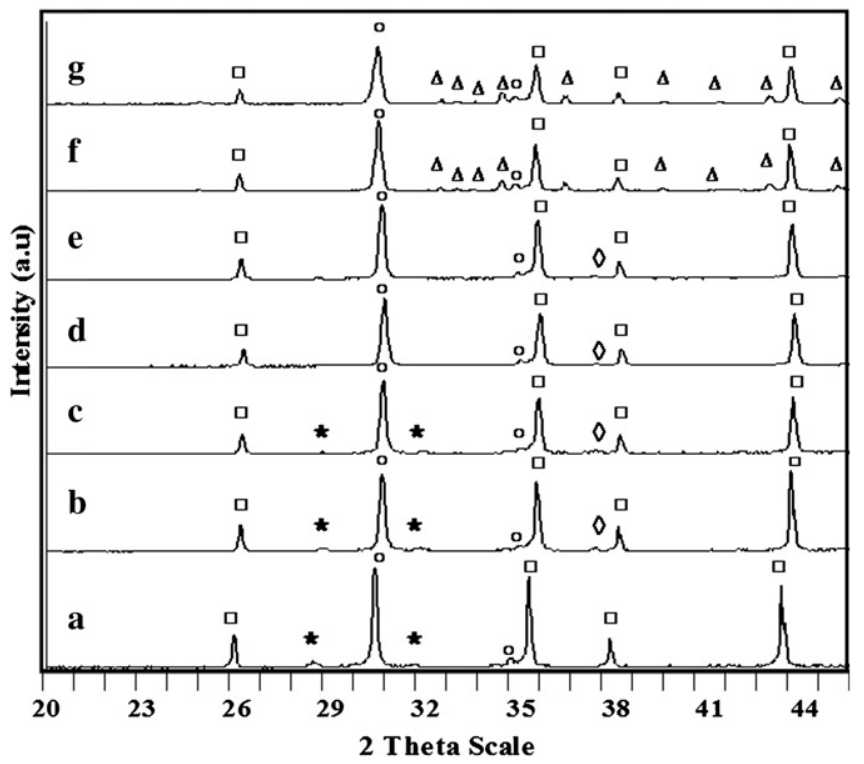

\begin{tabular}{|c|c|c|}
\hline$\square$ & $\alpha-\mathrm{Al}_{2} \mathrm{O}_{3}$ & $\Delta \mathrm{CeAl}_{11} \mathrm{O}_{18}$ \\
\hline 0 & $\mathrm{Zr}_{0.935} \mathrm{Y}_{0.065} \mathrm{O}_{1.968}$ & * $\mathrm{m}-\mathrm{ZrO}_{2}$ \\
\hline 0 & $\mathrm{MgAl}_{2} \mathrm{O}_{4}$ & \\
\hline
\end{tabular}

Fig. 5. XRD patterns of (a) ZTA, (b) ZTA-MgO, (c) ZTA-MgO-0.5 wt.\% $\mathrm{CeO}_{2}$, (d) ZTA$\mathrm{MgO}-0.7$ wt.\% $\mathrm{CeO}_{2}$, (e) $\mathrm{ZTA}-\mathrm{MgO}-1$ wt.\% $\mathrm{CeO}_{2}$, (f) $\mathrm{ZTA}-\mathrm{MgO}-5$ wt.\% $\mathrm{CeO}_{2}$, and (g) ZTA-MgO-7 wt.\% $\mathrm{CeO}_{2}$.

brought about by the crack diffusion process absorb the fracture energy and inhibit cracks from expanding to improve fracture toughness [23]. The result of Vickers hardness increased from 14.51 GPa to $14.99 \mathrm{GPa}$ with the addition of 1.0 wt.\% $\mathrm{CeO}_{2}$. However, the addition of more $\mathrm{CeO}_{2}$ led to a decrease in Vickers hardness values, from $14.99 \mathrm{GPa}$ to $14.15 \mathrm{GPa}$. The decrease of Vickers hardness is possibly due to the presence of secondary phase of $\mathrm{CeAl}_{11} \mathrm{O}_{18}$. Theoretically, polycrystalline materials with finer grain size would give higher Vickers hardness while materials with coarser grain size will give higher values of fracture toughness. In the current study, it was found that ZTA with $1.0 \mathrm{wt} . \%$ of $\mathrm{CeO}_{2}$ gave the highest Vickers hardness due to the maximum bulk density obtained $\left(4.28 \mathrm{~g} / \mathrm{cm}^{3}\right)$. The trend of Vickers hardness increased along with the results of bulk density only up to $1.0 \mathrm{wt}$.\% of $\mathrm{CeO}_{2}$. However, further addition of $\mathrm{CeO}_{2}$ caused the bulk density to decrease due to the presence of secondary phase $\mathrm{CeAl}_{11} \mathrm{O}_{18}$. The decrease of bulk density led to the decrease of Vickers hardness. For fracture toughness, the trend showed an increase until $1.0 \mathrm{wt} . \%$ of $\mathrm{CeO}_{2}$. The increase is attributed to the increase of $\mathrm{Al}_{2} \mathrm{O}_{3}$ grain size with further addition of $\mathrm{CeO}_{2}$. According to the grain size measurements in Fig. 8, it can be stated that $\mathrm{CeO}_{2}$ additions of $0.5-7.0$ wt.\% efficiently promoted grain growth of $\mathrm{Al}_{2} \mathrm{O}_{3}$. However, when the addition of $\mathrm{CeO}_{2}$ was $5 \mathrm{wt}$.\% and above, $\mathrm{CeAl}_{11} \mathrm{O}_{18}$ phase started to form and caused a decrease in the composite fracture toughness.

The appearance of $\mathrm{CeAl}_{11} \mathrm{O}_{18}$ is significant because it affects the fracture toughness and Vickers hardness of the $\mathrm{ZTA}-\mathrm{MgO}-\mathrm{CeO}_{2}$ composites. The presence of $\mathrm{CeAl}_{11} \mathrm{O}_{18}$ is confirmed by the representative micrographs of ZTA-MgO- $\mathrm{CeO}_{2}$ samples shown in Fig. 9. The bright and dark contrast grains correspond to $\mathrm{YSZ}$ and $\mathrm{Al}_{2} \mathrm{O}_{3}$ grains, respectively. The size of $\mathrm{Al}_{2} \mathrm{O}_{3}$ grains was inhibited due to the presence of YSZ grains. A similar micrograph observation was also reported by Azhar et al. The appearance of small fine grain size of $\mathrm{Al}_{2} \mathrm{O}_{3}$ is known to increase the hardness of ceramic composites. According to the grain size measurements in Fig. 8, it can be stated that $\mathrm{CeO}_{2}$ additions of $0.5-7.0$ wt.\% efficiently promote grain growth of $\mathrm{Al}_{2} \mathrm{O}_{3}$. Average grain size increased approximately $38 \%$ with the addition of $7.0 \mathrm{wt} . \%$ of $\mathrm{CeO}_{2}$. In this range, the largest 


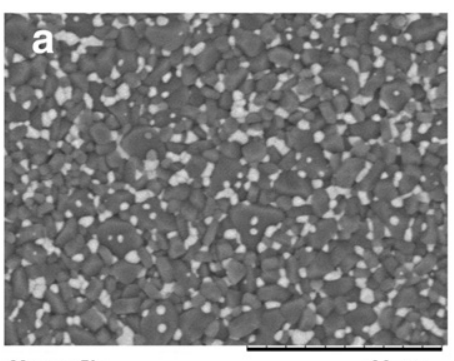

Mag $=\mathbf{5 k}$

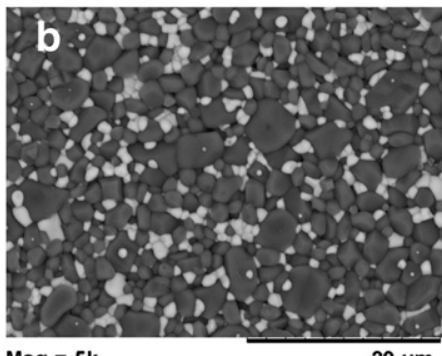

$\operatorname{Mag}=5 \mathrm{k}$

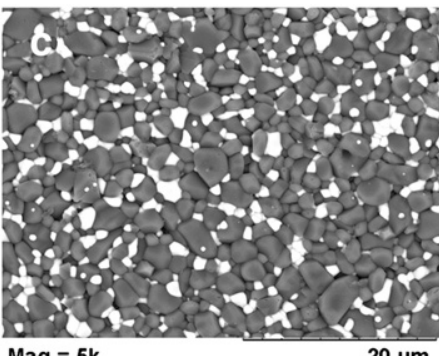

Mag $=5 \mathrm{k}$

$20 \mu \mathrm{m}$

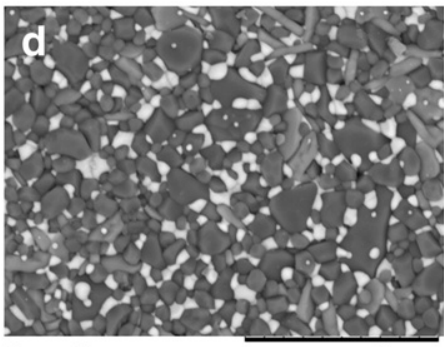

Mag $=\mathbf{5 k}$
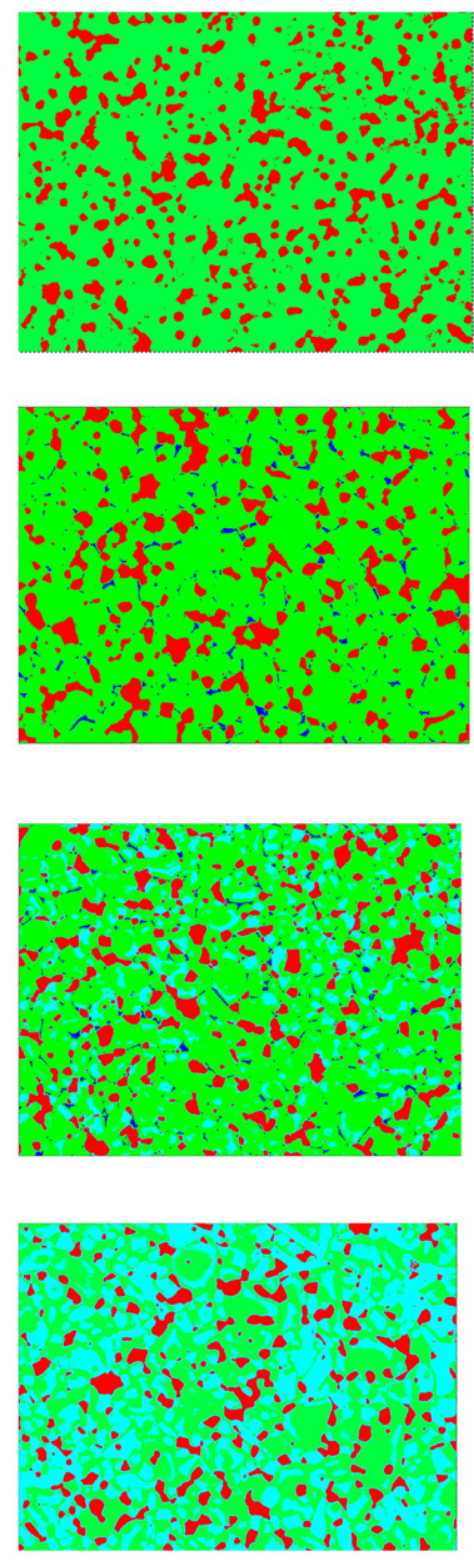
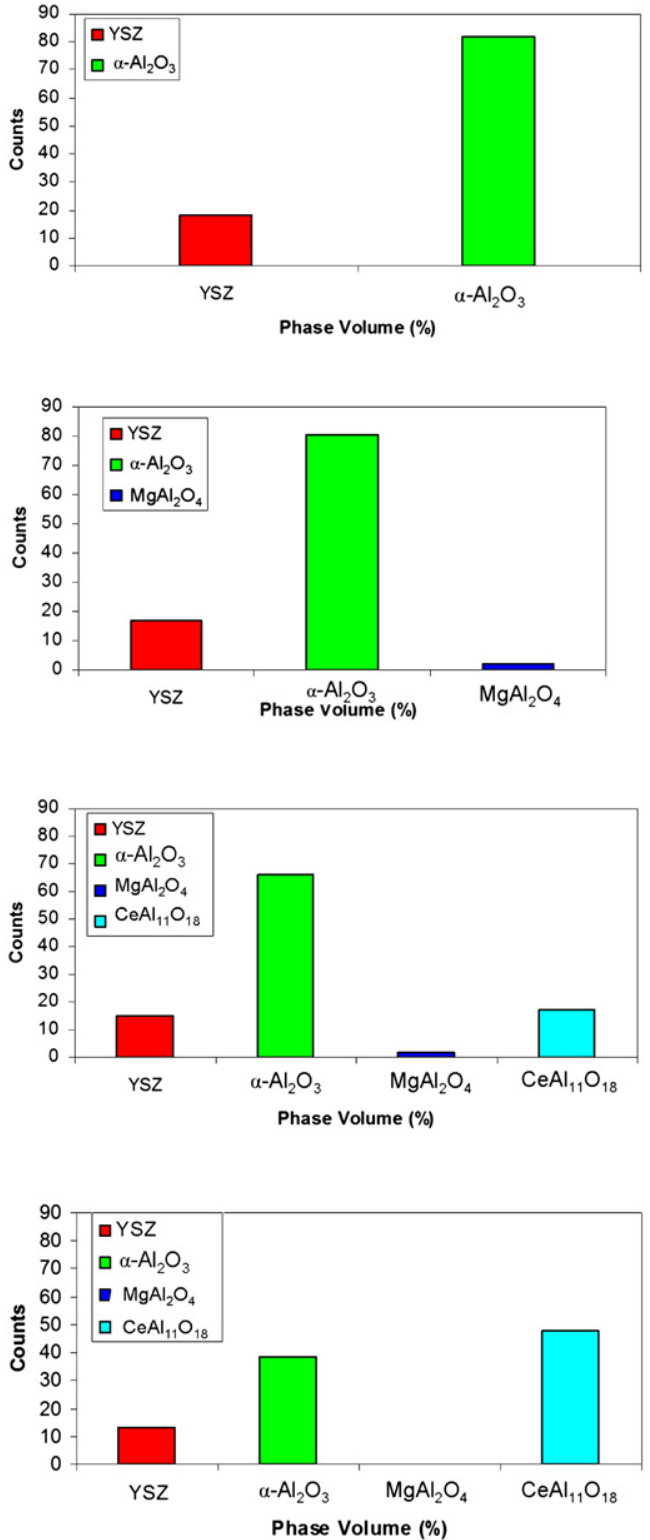

Phase Volume (\%)

Fig. 6. Quantitative phase analysis of (a) $\mathrm{ZTA}$, (b) $\mathrm{ZTA}-\mathrm{MgO}$, (c) $\mathrm{ZTA}-\mathrm{MgO}-1.0$ wt.\% $\mathrm{CeO}_{2}$, and (d) $\mathrm{ZTA}-\mathrm{MgO}-7.0$ wt.\% $\mathrm{CeO}_{2}$ based on their respective micrograph.

average grain size for $\mathrm{Al}_{2} \mathrm{O}_{3}$ obtained was the one corresponding to the sample with $5.0 \mathrm{wt} . \%(2.98 \pm 0.56 \mu \mathrm{m})$; the smallest average grain size was obtained for the sample ZTA-MgO without $\mathrm{CeO}_{2}$ addition $(2.14 \pm 0.82 \mu \mathrm{m})$. Furthermore, in the case of YSZ grains, the average grain size was $(1.70 \pm 0.41 \mu \mathrm{m})$ with increased $\mathrm{CeO}_{2}$ additions. The

Table 3

Phase area percentage for each composition in $\mathrm{ZTA}-\mathrm{MgO}-\mathrm{CeO}_{2}$ composites.

\begin{tabular}{llllc}
\hline \multirow{2}{*}{ Composition } & \multicolumn{4}{l}{ Phase area (\%) } \\
\cline { 2 - 5 } & $\mathrm{Al}_{2} \mathrm{O}_{3}$ & $\mathrm{YSZ}$ & $\mathrm{MgAl}_{2} \mathrm{O}_{4}$ & $\mathrm{CeAl}_{11} \mathrm{O}_{18}$ \\
\hline ZTA & 81.72 & 18.23 & 0.00 & 0.00 \\
$\mathrm{ZTA}-\mathrm{MgO}$ & 78.87 & 17.12 & 3.31 & 0.00 \\
$\mathrm{ZTA}-\mathrm{MgO}-0.5 \mathrm{CeO}_{2}$ & 76.15 & 18.39 & 4.43 & 0.00 \\
$\mathrm{ZTA}-\mathrm{MgO}-0.7 \mathrm{CeO}_{2}$ & 80.56 & 16.65 & 2.09 & 0.00 \\
$\mathrm{ZTA}-\mathrm{MgO}-1.0 \mathrm{CeO}_{2}$ & 66.07 & 14.80 & 1.73 & 17.28 \\
$\mathrm{ZTA}-\mathrm{MgO}-5.0 \mathrm{CeO}_{2}$ & 52.02 & 12.83 & 0.00 & 30.88 \\
$\mathrm{ZTA}-\mathrm{MgO}-7.0 \mathrm{CeO}_{2}$ & 38.54 & 13.08 & 0.00 & 47.66 \\
\hline
\end{tabular}

formation of elongated grains of $\mathrm{CeAl}_{11} \mathrm{O}_{18}$ in the matrix of finegrained $\mathrm{Al}_{2} \mathrm{O}_{3}$ was observed in the composites containing 5.0 and 7.0 wt.\% $\mathrm{CeO}_{2}$. Furthermore, the average length of $\mathrm{CeAl}_{11} \mathrm{O}_{18}$ grains was found to increase with the addition of $\mathrm{CeO}_{2}$. The formation of $\mathrm{CeAl}_{11} \mathrm{O}_{18}$ promotes bonding between $\mathrm{Al}_{2} \mathrm{O}_{3}$ and $\mathrm{CeO}_{2}$, which also has a contributing effect on the mechanical properties of the composite. Moreover, $\mathrm{CeO}_{2}$ exhibits sensitivity to the sintering atmosphere and can form nonstoichiometric oxides such as $\mathrm{Ce}_{2} \mathrm{O}_{3}$ when sintering at low oxygen pressure atmosphere [22]. As shown in Fig. 9, the addition of $\mathrm{CeO}_{2}$ above $5 \mathrm{wt}$.\% clearly shows the formation of $\mathrm{CeAl}_{11} \mathrm{O}_{18}$ elongated grains. These elongated grains of $\mathrm{CeAl}_{11} \mathrm{O}_{18}$ tend to have larger grain sizes. The average size of elongated $\mathrm{CeAl}_{11} \mathrm{O}_{18}$ grains is $4-6 \mu \mathrm{m}$ in length and $0.7-1 \mu \mathrm{m}$ in width. The average length of elongated grains increased with increasing $\mathrm{CeO}_{2}$ content from $5 \mathrm{wt} . \%(1.89 \pm 0.41 \mu \mathrm{m})$ to $7 \mathrm{wt} . \%$ $(1.91 \pm 0.45 \mu \mathrm{m})$.

Previous work done by Akin et al. also observed the formation of $\mathrm{CeAl}_{11} \mathrm{O}_{18}$ during spark plasma sintering (SPS) of $\mathrm{Al}_{2} \mathrm{O}_{3}-\mathrm{YSZ}_{-}-\mathrm{CeO}_{2}$ system. According to Akin et al., the presence of elongated $\mathrm{CeAl}_{11} \mathrm{O}_{18}$ grains 

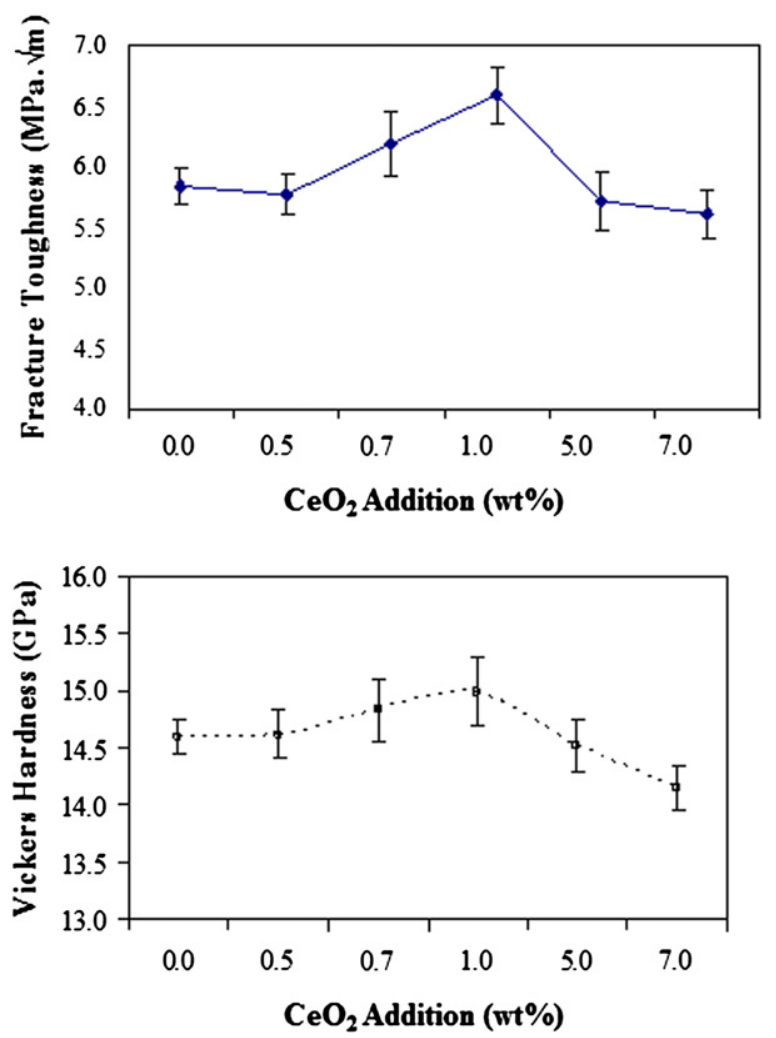

Fig. 7. Vickers hardness and fracture toughness of ZTA- $\mathrm{MgO}-\mathrm{CeO}_{2}$ compositions as a function of $\mathrm{CeO}_{2}$ wt.\%.

resulted in lower Vickers hardness and fracture toughness values compared to samples without the presence of $\mathrm{CeAl}_{11} \mathrm{O}_{18}$ grains. The Vickers hardness was reduced from $14.99 \pm 0.31 \mathrm{GPa}$ to $14.15 \pm 0.19 \mathrm{GPa}$ for samples with 1.0 wt.\% $\mathrm{CeO}_{2}$ to 7.0 wt.\% $\mathrm{CeO}_{2}$, respectively. The decrease of Vickers hardness is attributed to the change of $\mathrm{Al}_{2} \mathrm{O}_{3}$ grain size due to different $\mathrm{CeO}_{2}$ content. In polycrystalline materials, samples with finer grain size will have higher Vickers hardness compared to polycrystalline materials with a larger grain size. This is due to the movement of dislocations between grains. These movements of dislocations provide a mechanism for planes of atoms to slip and results in plastic or

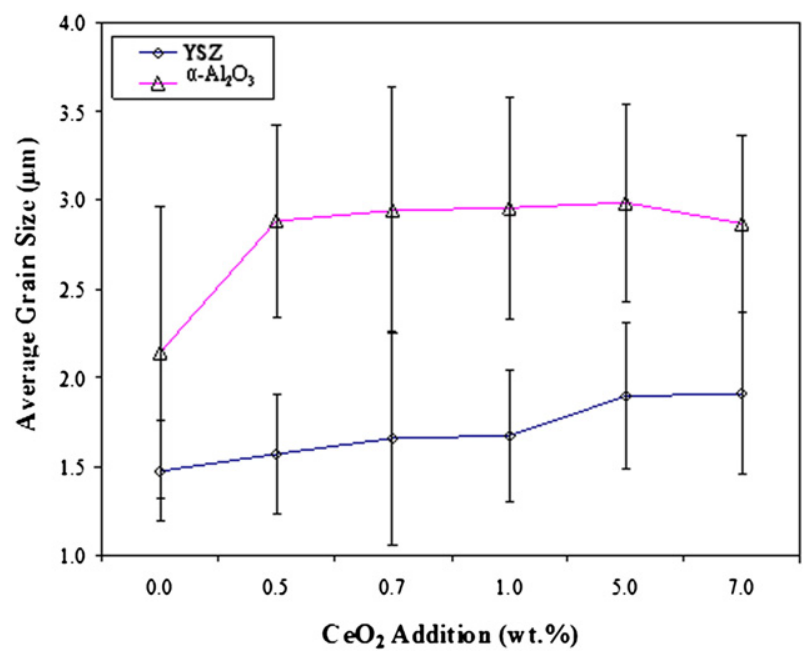

Fig. 8. Average grain size for both $\mathrm{ZrO}_{2}$ and $\mathrm{Al}_{2} \mathrm{O}_{3}$ grains with varied $\mathrm{CeO}_{2}$ addition in $\mathrm{ZTA}-$ $\mathrm{MgO}$ composites. permanent deformation. The movement allowed by these dislocations causes a decrease in the material's hardness. Furthermore, in polycrystalline materials, line defects or dislocations provide a mechanism for planes of atoms to slip, thus becoming a method for plastic or permanent deformation to happen. Planes of atoms can effectively flip from one side of the dislocation to the other, allowing the dislocation to traverse through the material and the material to deform permanently. The movement allowed by these dislocations causes a decrease in the material's hardness. When a dislocation intersects with a second dislocation, it can no longer traverse through the crystal lattice. The intersection of dislocations or crystal lattice with different arrangements of neighboring grains will create an anchor point and does not allow the planes of atoms to continue to slip over one another. For samples with finer grain size (ZTA-1.0 wt.\% $\mathrm{CeO}_{2}$ ), the movement of dislocations are restricted since the arrangement of crystal lattice is different to neighboring grains, creating more anchor points. Additional energy is required for the dislocation to traverse to neighboring grain, thus increasing the hardness.

The density of all samples was measured by Archimedes' principle using water as the immersion medium. The theoretical density of the sample was determined based on the rule of mixtures (ROM) for the composite ceramics prepared. A theoretical density of approximately $99.0 \%$ was obtained for all $\mathrm{ZTA}-\mathrm{MgO}$ and $\mathrm{ZTA}-\mathrm{MgO}-\mathrm{CeO}_{2}$ compositions.

Fig. 10 shows the comparison of theoretical density and bulk density of sintered ZTA-MgO composite as a function of $\mathrm{CeO}_{2}$ additions. The increment of bulk density values followed the theoretical values from 0.0 until 1.0 wt.\% of $\mathrm{CeO}_{2}$ additions. However, a decrease in bulk density was observed as the content of $\mathrm{CeO}_{2}$ increased. The $\mathrm{ZTA}-\mathrm{MgO}$ composition without $\mathrm{CeO}_{2}$ addition showed a density of $4.18 \mathrm{~g} / \mathrm{cm}^{3}$. In samples with $\mathrm{CeO}_{2}$ addition, densification was promoted and showed a maximum density at $1.0 \mathrm{wt} . \%$ of $4.28 \mathrm{~g} / \mathrm{cm}^{3}$. Further addition resulted in decreased density which corresponds to the presence of abnormal growth of elongated $\mathrm{CeAl}_{11} \mathrm{O}_{18}$ grains.

The Vickers hardness values were found to be highest in samples with the addition of $1.0 \mathrm{wt} . \% \mathrm{CeO}_{2}$. This is because the bulk densities observed were at maximum values $\left(4.28 \mathrm{~g} / \mathrm{m}^{3}\right)$ with $0.48 \%$ porosity and $6.59 \pm 0.23 \mathrm{MPa} \cdot \sqrt{ } \mathrm{m}$ of toughness. The densities calculated for samples within the range of 0.0 to 1.0 wt.\% of $\mathrm{CeO}_{2}$ addition were in line/ proportional with theoretical density. However, a contrary observation was found in samples with 5.0 to $7.0 \mathrm{wt}$.\% of $\mathrm{CeO}_{2}$ addition. It is suggested that the decrease is due to the presence of $\mathrm{CeAl}_{11} \mathrm{O}_{18}$ phase in ZTA-MgO ceramic. The addition of $\mathrm{CeO}_{2}$ at certain wt.\% (1.0-7.0 wt.\%) in ZTA-MgO composites were found to have contributed to the formation of elongated grains $\left(\mathrm{CeAl}_{11} \mathrm{O}_{18}\right)$ while the reduction in $\mathrm{ZTA}-\mathrm{MgO}$ toughness and densities is due to changes in grain shape during coarsening [24]. Another factor that is closely related to density is porosity. Porosity is a defect which affects the density the most because porosity is inversely proportional to density. However, this is contradictory to author's [25] works. In addition, it is common for the porosity to increase with an increase in density. The addition of various amounts of $\mathrm{CeO}_{2}$ (wt.\%) densified ZTA-MgO composites (Fig. 10). Thus, from Fig. 10 , it is believed that the presence of $\mathrm{CeAl}_{11} \mathrm{O}_{18}$ phases in ZTA$\mathrm{MgO}-\mathrm{CeO}_{2}$ composites has critically influenced the density and porosity of the final product.

\section{Conclusion}

Toughened ZTA-MgO ceramics with different amounts of $\mathrm{CeO}_{2}$ addition were prepared and then analyzed. The resulting microstructure differed in grain size and shape, depending on the amount of $\mathrm{CeO}_{2}$ added. The crack propagation behavior corresponds to each microstructure change with respect to these characteristics. The ZTA sample with 0.7 wt.\% MgO exhibited crack deflection with a fracture toughness value of $6.19 \pm 0.26 \mathrm{MPa} \cdot \sqrt{\mathrm{m}}$. However, the compositions with $\mathrm{CeO}_{2}$ addition of 0.5 to $1.0 \mathrm{wt}$.\% showed increased crack bridging and deflection with fracture toughness ranging from $5.78 \pm 0.16 \mathrm{MPa} \cdot \sqrt{ } \mathrm{m}$ to 

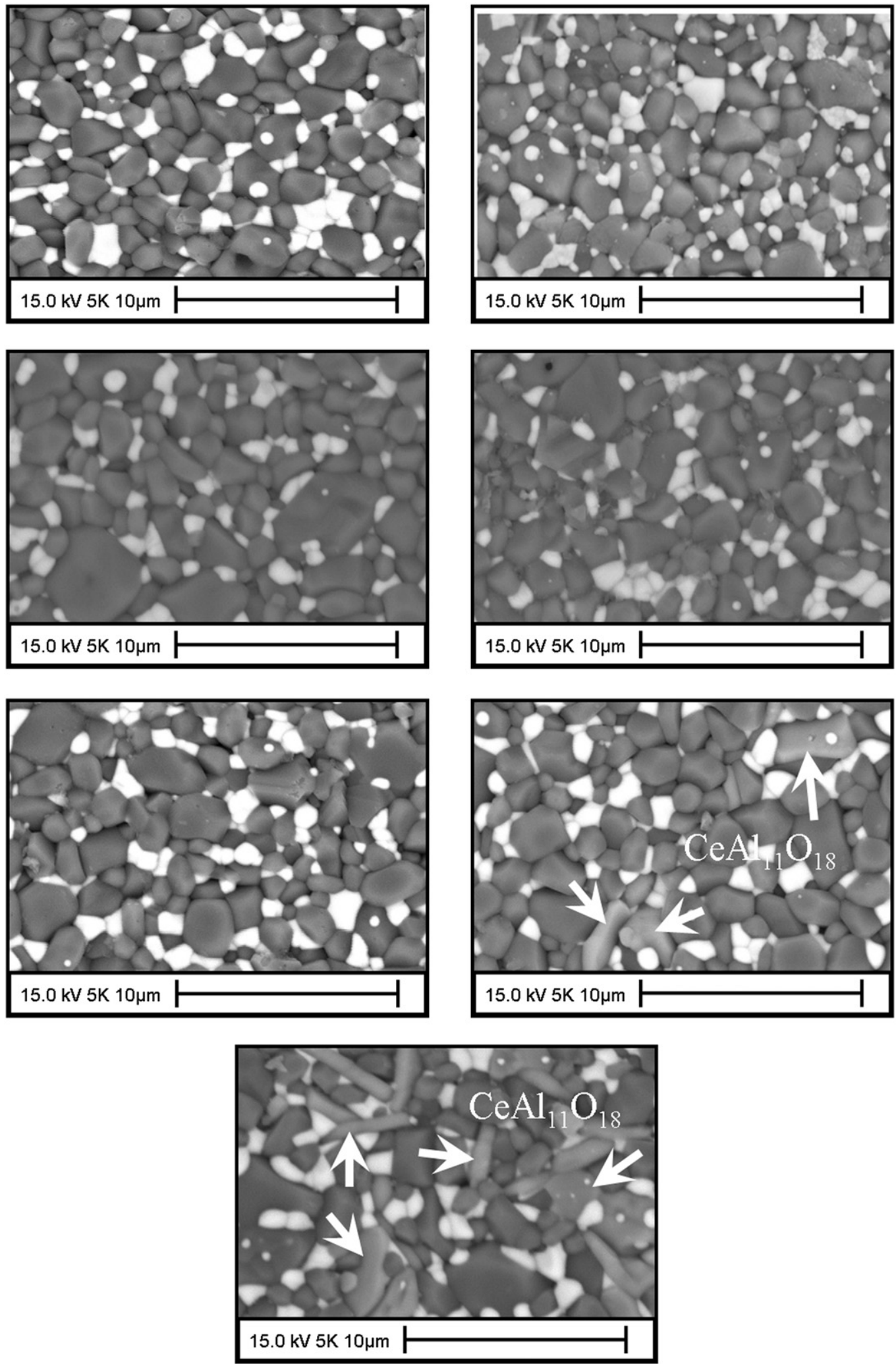

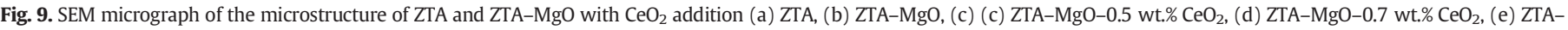
MgO-1.0 wt.\% $\mathrm{CeO}_{2}$, (f) ZTA-MgO-5.0 wt.\% $\mathrm{CeO}_{2}$, and (g) ZTA-MgO-7.0 wt.\% $\mathrm{CeO}_{2}$.

$6.59 \pm 0.23 \mathrm{MPa} \cdot \sqrt{ } \mathrm{m}$. The addition of $\mathrm{CeO}_{2}$ was found to significantly enhance both hardness and fracture toughness of ZTA-MgO composites. The Vickers hardness increased from $14.51 \mathrm{GPa}$ to $14.99 \mathrm{GPa}$ with the addition of 1.0 wt.\% $\mathrm{CeO}_{2}$, while the fracture toughness increased to
$6.59 \pm 0.23 \mathrm{MPa} \cdot \sqrt{ } \mathrm{m}$ with 1.0 wt.\% $\mathrm{CeO}_{2}$ addition. However, the presence of $\mathrm{CeAl}_{11} \mathrm{O}_{18}$ reduced the Vickers hardness and fracture toughness of the overall ceramics, which is in agreement with observations made by Akin et al. [22]. 
a

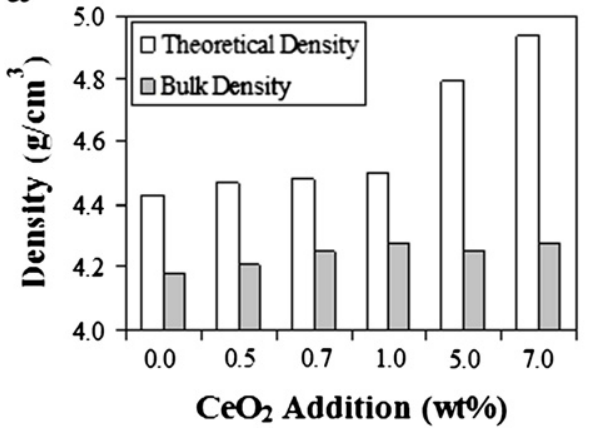

b

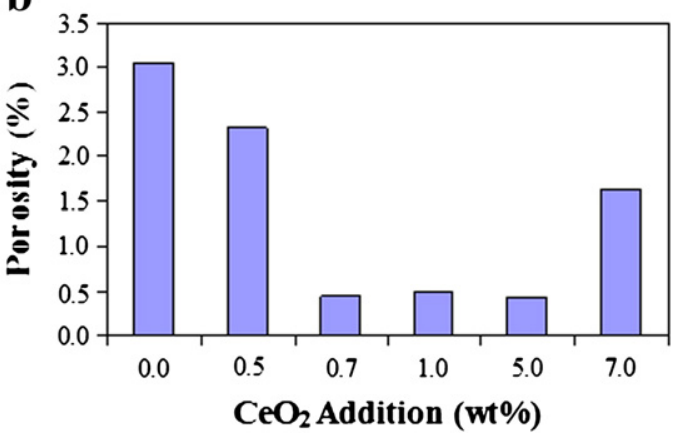

Fig. 10. Comparison of density of theoretical and bulk density for $\mathrm{ZTA}-\mathrm{MgO}-\mathrm{CeO}_{2}$ compositions.

\section{Acknowledgment}

This work was funded by Universiti Sains Malaysia (USM) under grant 1001/PBAHAN/811212 and MyBrain15. The authors are grateful to Dr. Anasyida Abu Seman, Mr. Mokhtar Mohamad, Mr. Sharul Ami, Mr. Wan Fahmin, Mr. Khairi, and Mr. Abdul Rashid for their technical support.

\section{References}

[1] Cesari F, Esposito L, Furgiuele FM, Maletta C, Tucci A. Fracture toughness of aluminazirconia composites. Ceram Int 2006;32:249-55.

[2] Maiti K, Sil A. Microstructural relationship with fracture toughness of undoped and rare earths (Y, La) doped $\mathrm{Al}_{2} \mathrm{O}_{3}-\mathrm{ZrO}_{2}$ ceramic composites. Ceram Int 2011;37:2411-21.

[3] Kosmac T, Swain M, Claussen N. The role of tetragonal and monoclinic $\mathrm{ZrO}_{2}$ particles in the fracture toughness of $\mathrm{Al}_{2} \mathrm{O}_{3}-\mathrm{ZrO}_{2}$ composites. Mater Sci Eng 1985;71:57-64.

[4] Shukla S, Seal S, Vij R. Effect of nanocrystallite morphology on the metastable tetragonal phase stabilization in zirconia. Nano Lett 2002;2:989-93.

[5] Do an CP, Hawk JA. Role of zirconia toughening in the abrasive wear of intermetallic and ceramic composites. Wear 1997;212:110-8.

[6] Smuk B, Szutkowska M. Alumina ceramics with partially stabilized zirconia for cutting tools. J Mater Proc 2003;133:195-8.

[7] Szutkowska M. Fracture resistance behavior of alumina-zirconia composites. J Mater Process Technol 2004;153-154:868-74.

[8] Basu B, Vleugels J, Biest OVD. $\mathrm{ZrO}_{2}-\mathrm{Al}_{2} \mathrm{O}_{3}$ composites with tailored toughness. J Alloys Compd 2004;372:278-84.

[9] Azhar AZA, Ratnam MM, Ahmad ZA. Effect of $\mathrm{Al}_{2} \mathrm{O}_{3} / \mathrm{YSZ}$ microstructures on wear and mechanical properties of cutting inserts. J Alloys Compd 2009;478:608-14.

[10] Azhar AZA, Mohamad H, Ratnam MM, Ahmad ZA. The effects of MgO addition on microstructure, mechanical properties and wear performance of zirconia-toughened alumina cutting inserts. J Alloys Compd 2010;497:316-20.

[11] Hao JKC, Azhar AZA, Ratnam MM, Ahmad ZA. Wear performance and mechanical properties of 80 wt.\% $\mathrm{Al}_{2} \mathrm{O}_{3} / 20$ wt.\% YSZ cutting inserts at different sintering rates and soaking times. Mater Sci Technol 2010;26:95-103.
[12] Azhar AZA, Mohamad H, Ratnam MM, Ahmad ZA. Effect of MgO particle size on the microstructure, mechanical properties and wear performance of ZTA-MgO ceramic cutting inserts. Int J Refract Metals Hard Mater 2011;29:456-61.

[13] Azhar AZA, Choong LC, Mohamed H, Ratnam MM, Ahmad ZA. Effects of $\mathrm{Cr}_{2} \mathrm{O}_{3}$ addition on the mechanical properties, microstructure and wear performance of zirconia-toughened-alumina (ZTA) cutting inserts. J Alloys Compd 2012;513: 91-6.

14] Rejab NA, Azhar AZA, Ratnam MM, Ahmad ZA. The effects of $\mathrm{CeO}_{2}$ addition on the physical, microstructural and mechanical properties of yttria stabilized zirconia toughened alumina (ZTA). Int J Refract Metals Hard Mater 2013;36:162-6.

[15] Niihara K. A fracture mechanics analysis of indentation-induced Palmqvist crack in ceramics. J Mater Sci Lett 1983;2:221-3.

[16] Wang J, Stevens R. Review: zirconia-toughened alumina (ZTA) ceramics. J Mater Sci 1989;24:3421-40.

[17] Mondal B, Chattopadhyay A, Virkar A, Paul A. Development and performance of zirconia-toughened alumina ceramic tools. Wear 1992;156:365-83.

[18] Basu B, Vleugels J, Biest OVD. Toughness tailoring of yttria-doped zirconia ceramics. Mater Sci Eng A 2004;380:215-21.

[19] Magnani G, Brillante A. Effect of the composition and sintering process on mechanical properties and residual stresses in zirconia-alumina composites. J Eur Ceram Soc 2005;25:3383-92.

20] Huang SG, Vanmeensel $\mathrm{K}$, Biest OVD, Vleugels J. Influence of $\mathrm{CeO}_{2}$ reduction on the microstructure and mechanical properties of pulsed electric current sintered $\mathrm{Y}_{2} \mathrm{O}_{3}-\mathrm{CeO}_{2}$ co-stabilized $\mathrm{ZrO}_{2}$ ceramics. J Am Ceram Soc 2007;90:1420-6.

[21] Sergo V, Vanni L, Giuseppe P, Elio L, Sergoio M, Naoki M, et al. The effect of wear on the tetragonal-to-monoclinic transformation and the residual stress distribution in zirconia-toughened alumina cutting tools. J Wear 1998;214:264-70.

[22] Akin I, Yilmaz E, Sahin F, Yucel O, Goller G. Effect of $\mathrm{CeO}_{2}$ addition on densification and microstructure of $\mathrm{Al}_{2} \mathrm{O}_{3}-\mathrm{YSZ}$ composites. Ceram Int 2011;37:3273-80.

[23] Senthil Kumar A, Raja Durai A, Sornakumar T. Development of yttria and ceria toughened alumina composite for cutting tool application. Int J Refract Metals Hard Mater 2007;25:214-9.

[24] Oh UC, Chung YS, Kim DY, Yoon DN. Effect of grain growth on pore coalescence during the liquid-phase sintering of $\mathrm{MgO}_{-}-\mathrm{CaMgSiO}_{4}$ systems. J Am Ceram Soc 1988;71: 854-7.

[25] German R, editor. Critical reviews in solid state and materials sciences, vol. 354 California: Taylor \& Francis; 2010. 